\title{
Casus E. - Visuele en conceptuele problemen tegen de achtergrond van een zich herstellende afasie
}

\author{
Hannelore van der Velden ${ }^{1}$ en Edith Denisse ${ }^{2}$ \\ ${ }^{1}$ De Hoogstraat Revalidatie, Utrecht \\ ${ }^{2}$ De Hoogstraat Revalidatie, Utrecht (tot 2016)
}

\begin{abstract}
Samenvatting
In deze casus worden de klinische dilemma's met betrekking tot taaldiagnostiek en afasietherapie in de verschillende revalidatiefasen van patiënte E. beschreven. E. kreeg een CVA, hetgeen resulteerde in stoornissen op het gebied van taal, visuele waarneming en conceptformatie. Zij maakte een langdurige revalidatieperiode door, met intensieve therapie, waarbij haar globale afasie evolueerde naar specifieke lees- en schrijfproblemen. Na een korte introductie van deze complexe casus worden de stappen in diagnostiek, therapie en begeleiding van deze patiënte beschreven.
\end{abstract}

\begin{abstract}
Summary
In this article, clinical dilemmas in language diagnostics and language therapy are discussed for the consecutive stages of rehabilitation in the case of patient E. E. suffered from a stroke, resulting in aphasia and disorders in visual perception and concept formation. Diagnostics, therapy and support will be described after an introduction of this complex case. E. went through a long-lasting rehabilitation period, in which the clinical syndrome evolved from global aphasia to more specific problems in reading and writing.
\end{abstract}

\section{Inleiding}

Bij patiënten met een CVA wordt de communicatie vaak beïnvloed door visuele waarnemingsproblemen (Bastiaanse, 2010a). In deze casusbeschrijving van E. is sprake van stoornissen in zowel de non-verbale semantiek ('concepten'), als in de visuele waarneming en taal. Dit spectrum aan stoornissen was zo breed dat de voor de klinische praktijk standaard linguïstische en neuropsychologische tests niet volstonden. Het effect van de stoornissen op de communicatie was echter dusdanig groot dat verder gezocht moest worden naar de

Drs. Hannelore van der Velden, De Hoogstraat Revalidatie, Rembrandtkade 10, 3583 TM, Utrecht. E-mail: h.v.d.velden@dehoogstraat.nl 
onderliggende stoornissen en aanknopingspunten voor therapie. Daarom hebben veel disciplines zich over de diagnostiek bij deze casus gebogen: neuroloog, neuropsycholoog, logopedist, klinisch linguïst, oogarts, optometrist/low-visionspecialist en een GZ-psycholoog gespecialiseerd in visuele problemen.

Ook de 'standaard' taaltherapie bleek niet toereikend: woordvindingstherapie en taalbegripsoefeningen werden bemoeilijkt door de problemen in de visuele waarneming. In de therapie werden taaloefeningen daarom vooral aangeboden in een functionele context, wat in de praktijk neerkwam op het stimuleren van een goede concept-activatie. Dit houdt in dat de eigenschappen van een voorwerp of handeling uit het dagelijks leven van E. werden doorgenomen, zowel verbaal als non-verbaal, met als doel om de juiste, bijbehorende mentale representaties te activeren. De problemen die we hierin tegenkwamen, konden we echter niet onderzoeken met de beschikbare tests. De Semantische Associatie Test (SAT; Visch-Brink, Stronk, \& Denes, 2005) die normaal gesproken gebruikt wordt om de visuele en verbale semantische verwerking te onderzoeken, bleek niet op betrouwbare wijze afneembaar juist door het brede scala aan stoornissen die elkaar sterk leken te beïnvloeden.

Intensieve, integrale multidisciplinaire diagnostiek en observaties bleken een passend alternatief. Het maakte de diagnostiek en behandeling zeer uitgebreid en complex maar ook boeiend en de moeite van het delen waard. Na een korte introductie van deze complexe casus worden de diagnostiek, therapie en begeleiding in de verschillende revalidatiefasen van deze patiënte beschreven.

\section{Introductie Casus E.}

E. is een 68-jarige vrouw die een CVA doormaakte. Op de CT-scan werden infarceringen gezien in de linkerhemisfeer (caudatus, frontoparietaal en occipitaal) en een kleinere infarcering rechts cerebellair. Vier weken post-onset werd E. klinisch opgenomen bij De Hoogstraat Revalidatie. Een samenvatting van haar toestand wordt hieronder in Figuur 1 weergegeven in een ICF-model. Het meest opvallend bij opname waren de communicatieproblemen en een verminderde visus. Aanvankelijk was E. emotioneel ontredderd, snel overprikkeld en onzeker in haar hele functioneren. De eerste maand na opname stond daarom in het teken van het ondersteunen van E. en haar familie en het bieden van zoveel mogelijk stabiliteit en structuur.

Vanwege haar afasie werd zij bij opname door de revalidatiearts aangemeld voor logopedie en linguïstisch onderzoek. In de communicatie had E. in de eerste weken na opname moeite om zich te uiten, het begrijpen van taal in een duidelijke, voorspelbare context verliep redelijk. Lezen en schrijven lukten geheel niet. 


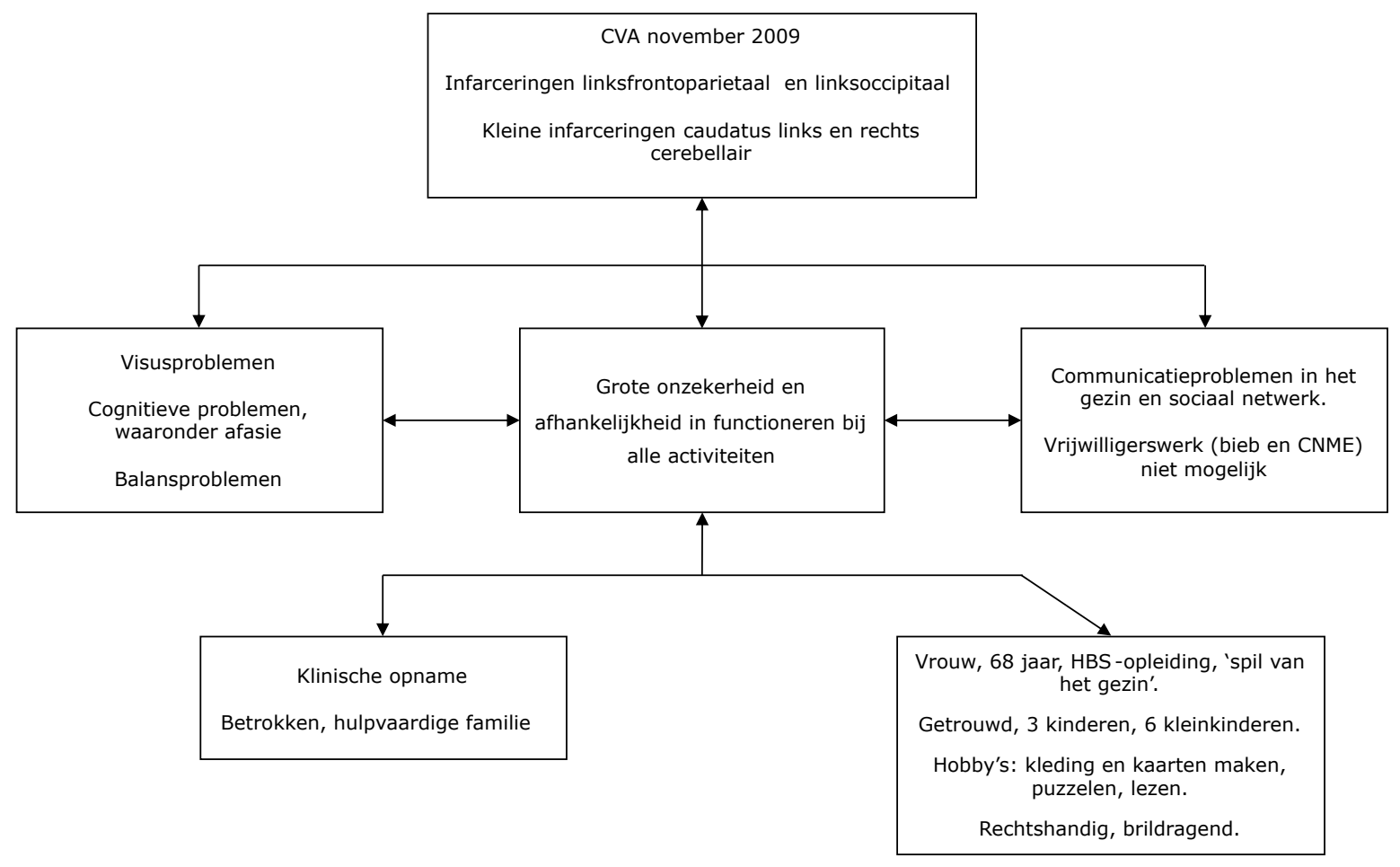

Figuur 1: ICF-model van E.

\section{Diagnostiek}

Twee maanden post-onset was E. neurologisch en emotioneel stabiel genoeg voor diagnostisch onderzoek en werd er een algemene neuropsychologische screening aangevraagd, die drie maanden post-onset werd afgenomen (februari 2010). Daarnaast werd er logopedisch en linguïstisch onderzoek opgestart. Een uitgebreid overzicht van de taaldiagnostiek is weergegeven in Bijlage A van dit artikel.

Het in kaart brengen van de taalvaardigheid van E. werd bemoeilijkt door visuele problemen die haar parten speelden: het lezen lukte niet en E. begreep afbeeldingen vaak niet goed. Hierdoor was de bij afasie tot voor kort gebruikelijke afname van de Akense Afasie Test (AAT; Graetz, De Bleser, \& Willmes, 1992) grotendeels onmogelijk. Omdat de aard van deze visuele problemen aanvankelijk nog onduidelijk was, is het taalonderzoek uitgevoerd in nauw overleg met een neuropsycholoog en zijn er ook taaltests afgenomen die geen beroep deden op visuele vaardigheden, zoals de Verbale Boston Benoemtaak (VBBT; Roomer, Brok, Hoogerwerf \& Linn, 2011), waarbij E. voorwerpen benoemde op basis van een auditief aangeboden definitie. Ook een aantal auditieve taken van de Psycholinguistic Assessment of Linguistic Processing in Aphasia (PALPA; Bastiaanse, Bosje, \& Visch-Brink, 1995) kon worden afgenomen, zoals de auditieve synoniembeoordeling (PALPA-taak 47). Bij deze taak beoordeelde E. of twee gesproken woorden in betekenis gelijk zijn.

In de neuropsychologische screening werden aanwijzingen gevonden voor problemen 
Tabel 1: Prestaties op en aanverwante vaardigheden bij BE-2 van de AAT

\begin{tabular}{lllll}
\hline Kleur & Benoemen & $\begin{array}{l}\text { Benoemen } \\
\text { omschrijving }\end{array}$ & $\begin{array}{l}\text { n.a.v. } \\
\text { Matchen in } \\
\text { de ruimte }\end{array}$ & $\begin{array}{l}\text { Matchen met } \\
\text { afbeelding }\end{array}$ \\
\hline Rood & + & n.v.t. & + & + \\
Wit & + & n.v.t. & + & + \\
Groen & X ('grijs') & + & X & + \\
Zwart & X ('paars') & + & $X$ & X \\
Geel & X ('groen') & X (perseveratie?) & + & X \\
Blauw & X ('geelachtig, donkergeel') & X & + & X \\
Bruin & + & n.v.t. & + & + \\
Grijs & X ('ook een beetje geelachtig') & X & X & X \\
Paars & + & n.v.t. & X & + \\
Oranje & X ('ook lila') & + & + & + \\
\hline
\end{tabular}

- Groen: 'grijs'. TL zegt: 'Het is de kleur van de blaadjes aan de bomen'. E. zegt: 'Oh, dan is het groen.' E. wijst de appel aan.

- Oranje: 'ook lila'. TL zegt: 'Nee, het is geen lila. Het is onze nationale kleur.' E. zegt: 'O, dan is het oranje.' E. wijst de vis aan en zegt: 'Als die vis oranje is, is het een goudvis.'

Het benoemen n.a.v. de kleur uit de testmap ging goed als E. de kleur goed kon matchen met afbeeldingen (abstracte betekenisactivatie/concept). Als dit niet lukte, ging het benoemen ook niet goed, ook niet n.a.v. een gegeven omschrijving.

in de visuele waarneming, het verwerken en overzien van visuele informatie en in de herkenning van objecten. In samenspraak met de neuropsycholoog is de samenhang tussen visuele waarneming en de benoemvaardigheid nader onderzocht door de kleurbenoemtaak uit de AAT (BE-2) op een uitgebreidere manier af te nemen: op het moment dat E. de getoonde kleur niet kon benoemen, werd aan E. een omschrijving gegeven van de kleur en mocht E. een nieuwe benoempoging doen. Verder werd haar gevraagd om de desbetreffende kleur in de ruimte aan te wijzen, en vervolgens een afbeelding te kiezen (uit twee) van een voorwerp dat dezelfde kleur heeft (bv. bij de kleur rood kiezen tussen een afbeelding van een banaan en een afbeelding van kersen). De resultaten van deze uitgebreidere afname staan in Tabel 1 vermeld, met nog een aantal observaties.

Ook met een aantal items uit PALPA 51 werd het benoemen behandelend onderzocht. In het voorbeeld hieronder is het doelwoord kip. De voorafgaande afbeelding was trein. De opname van afname van dit item is te bekijken op: www . dehoogstraat . nl/casuse ('fragment kip'). 


\author{
L.: Kunt $\mathrm{u}$ het omschrijven of uitleggen wat u ziet? \\ E.: Ik ga nu weer dezelfde woorden noemen, benoemen, merk ik. \\ L.: Kunt u er iets meer over vertellen? Helpt dat? \\ E.: Deel van een trein? Ja, het is een trein. \\ L.: Het is een dier, hè? Hoe groot is die, denkt $u$ ? Vanaf de tafel? \\ E.: Zoiets. (E. geeft de grootte aan.) \\ L.: Ja, en wat doet-ie? \\ E.: Kakelen. \\ L.: Ja. En het legt ook eieren, hè? \\ E.: Kip!
}

Uit de neuropsychologische screening (afgenomen rond drie maanden post-onset) bleek dat E. moeite had met het verdelen van aandacht. Daarnaast bleken de visuele aandachtsspanne en het geheugen (inprenting en opdiepen) gestoord. Perseveraties kwamen voor in het benoemen, niet in het handelen. Het probleemoplossend vermogen was verminderd. E. werkte nauwkeurig en controleerde zichzelf goed.

Verder bleken uit de neuropsychologische screening en uit observaties tijdens het linguïstisch onderzoek problemen in de visuele waarneming, met name in het herkennen en overzien van afbeeldingen, voorwerpen én geschreven woorden. Desondanks bleek het lastig om tot een duidelijke diagnose te komen zonder specialistisch onderzoek naar de visuele problemen. Daarom werd E. voor vervolgonderzoek naar een oogarts en naar Bartimeús ${ }^{1}$ doorverwezen. Uit het onderzoek door de oogarts bleek de visus verminderd. Met beide ogen kon ze echter $90 \%$ zien. Het vervolgonderzoek door Bartimeús toonde duidelijk een homonieme hemianopsie rechts waardoor het overzicht en de visuele waarneming gefragmenteerd raakten. Daardoor moest ze een groter beroep doen op het scannen van visuele informatie, hetgeen haar extra vermoeide. Tevens was sprake van een subjectief crowdingeffect: ze raakte snel visueel overprikkeld. Tot slot bleek dat er geen sprake was van een visuele agnosie, maar wel van semantische verwarringen naar aanleiding van visueel materiaal.

Dat het geheel aan visuele problemen het lezen negatief beïnvloedde, was evident. Maar

\footnotetext{
${ }^{1}$ Bartimeús is de grootste organisatie in Nederland voor dienstverlening aan visueel gehandicapten waarbij uitgebreid en specialistisch visusonderzoek wordt verricht.
} 
een sluitende verklaring voor de leesproblemen werd in het visueel vervolgonderzoek niet gevonden.

De voorlopige logopedische diagnose luidde aldus: afasie met problemen in alle taalmodaliteiten. Onderliggend bleek uit PALPA 47 sprake van een lexicaal-semantische stoornis, en op basis van de benoemproblemen van vooral laagfrequentere begrippen een stoornis in het fonematisch outputlexicon (FOL). Dit laatste was echter niet betrouwbaar vast te stellen, omdat de Verbale Boston Benoemtaak niet taalkundig gewogen is voor woordfrequentie. De onderliggende visuele problemen met objectherkenning en met het overzien van grotere gehelen, hingen mogelijk samen met de bij het taalonderzoek gevonden stoornissen: een ernstige stoornis in de visuele semantiek en alexie. De alexie was perifeer: er waren problemen met visuele analyse, namelijk problemen met het bepalen van de letterpositie in een woord. Dit veroorzaakte secundaire problemen met visuele woordherkenning (VIL). Daarnaast was sprake van een ernstige agrafie, veroorzaakt door een stoornis in het grafemisch outputlexicon en een ernstige stoornis op het allografisch niveau. In Figuur 2 zijn de taalproblemen van E. schematisch weergegeven.

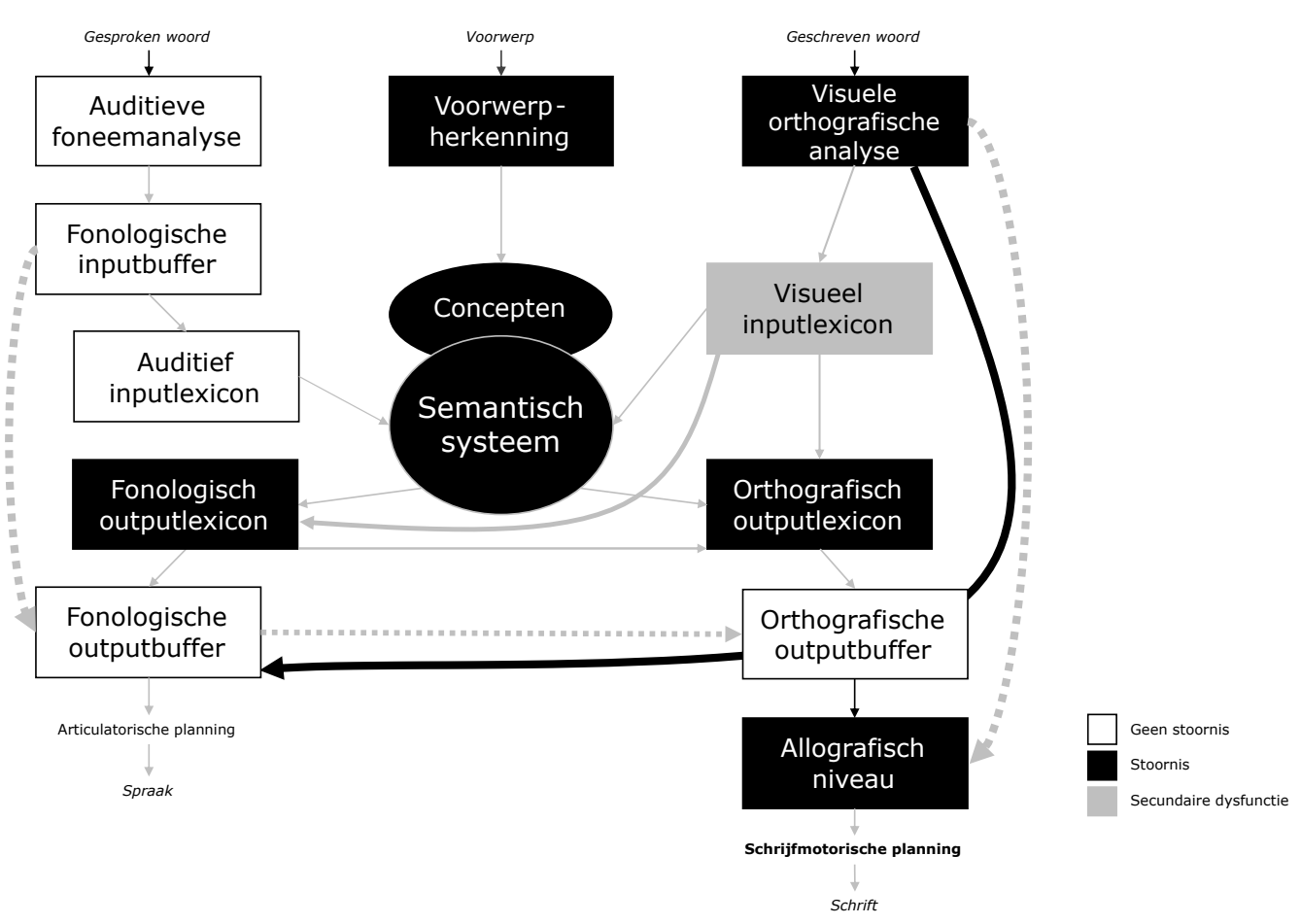

Figuur 2: De onderliggende taalstoornissen van E. in kaart gebracht naar het logogenmodel van Patterson \& Shewell (1987) en het taalverwerkingsmodel op woordniveau uit de Palpa (Bastiaanse, Bosje \& Visch-Brink, 1995). 


\section{Klinische en poliklinische behandeling}

\section{Behandelperiode 1}

Een belangrijk doel voor E. was het lezen. Voor haar echtgenoot waren het herstel van cognitieve functies zoals geheugen, visus, en 'zich beter duidelijk kunnen maken' de belangrijkste hulpvragen. De logopedische doelen zijn vermeld in Bijlage B.

De ontreddering bij E. en haar partner waren aanvankelijk het meest belemmerende probleem. Daarom werd gestart met gesprekken met de logopedist, de maatschappelijk werker, E., haar echtgenoot en hun zoons. Meer informatie over deze combi-gesprekken is te vinden onder www . dehoogstraat.nl/gesprekmetafasie/.

De visuele waarnemingsproblemen, de overprikkeling en de problemen in het switchen van taken beperkten ons in de keuze van de behandelmethoden en -materialen. Zo konden we aanvankelijk geen gebruik maken van methodes als Auditief Taalbegrips Programma (Bastiaanse, 2010b) of BOX (Visch-Brink \& Bajema, 2001). Daarom werden zoveel mogelijk dagelijkse communicatieve situaties geoefend (participatieniveau), en waar nodig op stoornisniveau verdiept. Met behulp van de BIPAC (Heesbeen \& Sevat, 2001) werd geïnventariseerd wat voor E. het belangrijkst was om haar zelfredzaamheid en motivatie te vergroten. Eén van de concrete doelen was het lezen van etiketten. E. deed hiermee in de therapie succeservaringen op, naast andere praktische situaties, waardoor ze thuis actiever en zelfstandiger werd. Bij ontslag uit de kliniek (vier maanden post-onset) had E. meer zelfvertrouwen, in communicatie en praktische situaties.

Na het ontslag uit de kliniek kwam E. driemaal per week naar het revalidatiecentrum voor dagbehandeling. In de logopedische behandeling kwamen het 'lezen' van de krant, telefoneren, een boodschappenbriefje schrijven en het eigen maken van self-cueing bij woordvindingsproblemen aan bod.

Zes maanden post-onset wilde E. niet meewerken aan een herhalingsonderzoek. Voor evaluatie van de behandeling waren we daarom aangewezen op de observaties van de behandelend logopedisten. Deze zijn vermeld in Bijlage C, onder de kolom 'Uitkomsten' van de tabellen.

Aan het einde van de dagbehandelingsperiode (negen maanden post-onset) kon E. thuis de telefoon aannemen en een mededeling doorgeven aan haar echtgenoot. Het schrijven van een veelvoorkomend woord (een boodschap) lukte soms, maar teruglezen was niet mogelijk waardoor de verbetering in het schrijven geen functionele winst opleverde voor E.

\section{Behandelperiode 2 (1;9 jaar post-onset; nieuwe hulpvraag)}

Pas toen vanuit het revalidatiecentrum weer contact met E. opgenomen werd voor onderwijsdoeleinden, kwam E. met een concrete hulpvraag over het lezen (en in mindere mate het schrijven). Er werd besloten tot een vervolgtraject. E. was nu voor het eerst bereid om aan een beknopte hertest mee te werken. Bij deze diagnostiek werden onderliggende stoornissen in het (functioneel) lezen en schrijven onderzocht. Belangrijke onderzoeksvragen waren 
of de voorwaarden om cues toe te passen en eigen te maken voldoende aanwezig waren en of er herstel in de taalfunctie was opgetreden ten opzichte van de eerste testafname.

Bij vergelijking van de uitkomsten van met de uitkomsten van de allereerste testafname bleek dat de lexicale semantiek en het hardop lezen significant verbeterd waren. Uitgebreidere diagnostiekgegevens zijn weergegeven in Bijlage D.

Nog steeds was sprake van een lichte afasie, met daarnaast alexie en agrafie.

Er bevonden zich nog stoornissen in het visueel analyse systeem, het visueel inputlexicon, de beide outputlexica en in de grafeem-foneemomzetter en vice versa. Uit afname van PALPA 47 bleek dat de lexicale semantiek was hersteld, maar uit de resultaten van de visuele subtest van de SAT bleek er nog altijd sprake van een visueel-semantische stoornis.

Bij de test staat één afbeelding in het midden, daaromheen vier andere afbeeldingen. E. werd gevraagd welke van de vier omringende afbeeldingen qua betekenis het meest gerelateerd is aan de afbeelding in het midden. Het aanwijzen van de afbeelding met de sterkste semantische associatie, is een correcte respons. E. bleek de Visuele SAT niet te kunnen volbrengen zonder hulp. Deze moeite met de taak leek niet op zichzelf te staan: wij vermoedden een associatieve visuele agnosie, naast het eerder gevonden crowding effect: betekenisverwarring naar aanleiding van afbeeldingen en visueel aangeboden voorwerpen. Daarom werd de testafname weliswaar afgebroken voor de testscoring, maar werd nog een aantal items afgenomen om te observeren hoe E. met hulp tot het juiste antwoord kon komen. Het viel op dat ze probeerde om de afbeelding in het midden te benoemen, maar daarbij werd afgeleid door de omliggende afbeeldingen: bij de afbeelding van de hand zei ze: 'mouw of trui' (op de bladzijde staat ook een trui). Bij de afbeelding van de lucifers zei ze: 'waxinelichtje' (op de bladzijde staat ook een kaars afgebeeld). Toen duidelijk werd dat E. afgeleid werd door de omliggende afbeeldingen en last had van de hoeveelheid informatie, werd ervoor gekozen om af te wijken van de standaard afname en de omliggende afbeeldingen af te dekken met een wit vel. Toen de omliggende afbeeldingen waren afgedekt, lukte het haar meestal wél om direct de afbeelding juist te benoemen. Vervolgens kon ze ook vlot de meest verwante afbeelding aanwijzen, zodra het witte afdekvel werd verwijderd. Als dit niet meteen lukte, gebruikte E. taal om te komen tot de juiste conceptformatie. Hierdoor werd duidelijk dat de problemen met de Visuele SAT los stonden van een mogelijke taalstoornis en een eventuele visueel-semantische stoornis de taalproductie niet negatief beïnvloedde. Het was door de aangepaste afname echter niet vast te stellen of de semantische conceptformatie verbeterd was ten opzichte van het eerdere testmoment. Zie ter illustratie het filmfragment 'vork' op www . dehoogstraat.nl/casuse.

Deze testresultaten wijzen erop dat E. beperkt, maar toch enigszins in staat moest zijn om zichzelf te leren cuen. Hierop werd besloten om logopedische behandeling voor het lezen en het schrijven op functieniveau op te starten. Om de kans op een therapie-effect te vergroten, moest intensieve therapie worden gestart. De echtgenoot van E. was bereid om dagelijks de rol van co-therapeut te vervullen, waardoor E. frequent de lees- en schrijfoefeningen herhaalde. E. kwam wekelijks 60 minuten naar De Hoogstraat Revalidatie voor behandeling door de logopedist en klinisch linguïst, samen met haar echtgenoot. De doelen en de therapie-inhoud zijn volledig weergegeven in Bijlage E (Tabel E1 en E2). 
Na vier weken intensief oefenen, merkten zowel E. als de behandelaars vooruitgang in het lezen en schrijven. De vooruitgang in het lezen en schrijven werd overgedragen aan het afasiecentrum, waar vervolgens speciaal voor E. een ABC-toetsenbord met grote letters werd aangeschaft. Eerder was E. nog niet in staat geweest om een toetsenbord te gebruiken.

Ter evaluatie van de geboden begeleiding werd een jaar later ${ }^{2}$ een beknopte hertest afgenomen voor met name het lezen en schrijven. Het meest opvallende resultaat op de hertest was een significante verbetering in het schrijven (gemeten met PALPA 51 - Schriftelijk Benoemen): eenvoudige hoogfrequente woorden schreef $\mathrm{E}$. nu vlot en foutloos.

E. vond dat het lezen vooruitgegaan was, maar een significante verandering kwam niet uit de testscore. Lezen bleef beperkt tot hoogfrequente vierletterwoorden of woorden met veel context (bijv. in een krant de kernwoorden met begeleidende foto). Omdat het lezen wisselend en vaak 'radend' verliep, kon E. in het dagelijks leven nauwelijks gebruik maken van het lezen. Dit maakte dat zij uiteindelijk het schrijven ook minder gebruikte: zij was niet in staat om zichzelf te controleren.

In Figuur 3 zijn de taalproblemen van E. schematisch weergegeven. Voor een uitgebreidere samenvatting van de hertest: zie Bijlage $\mathrm{F}$.

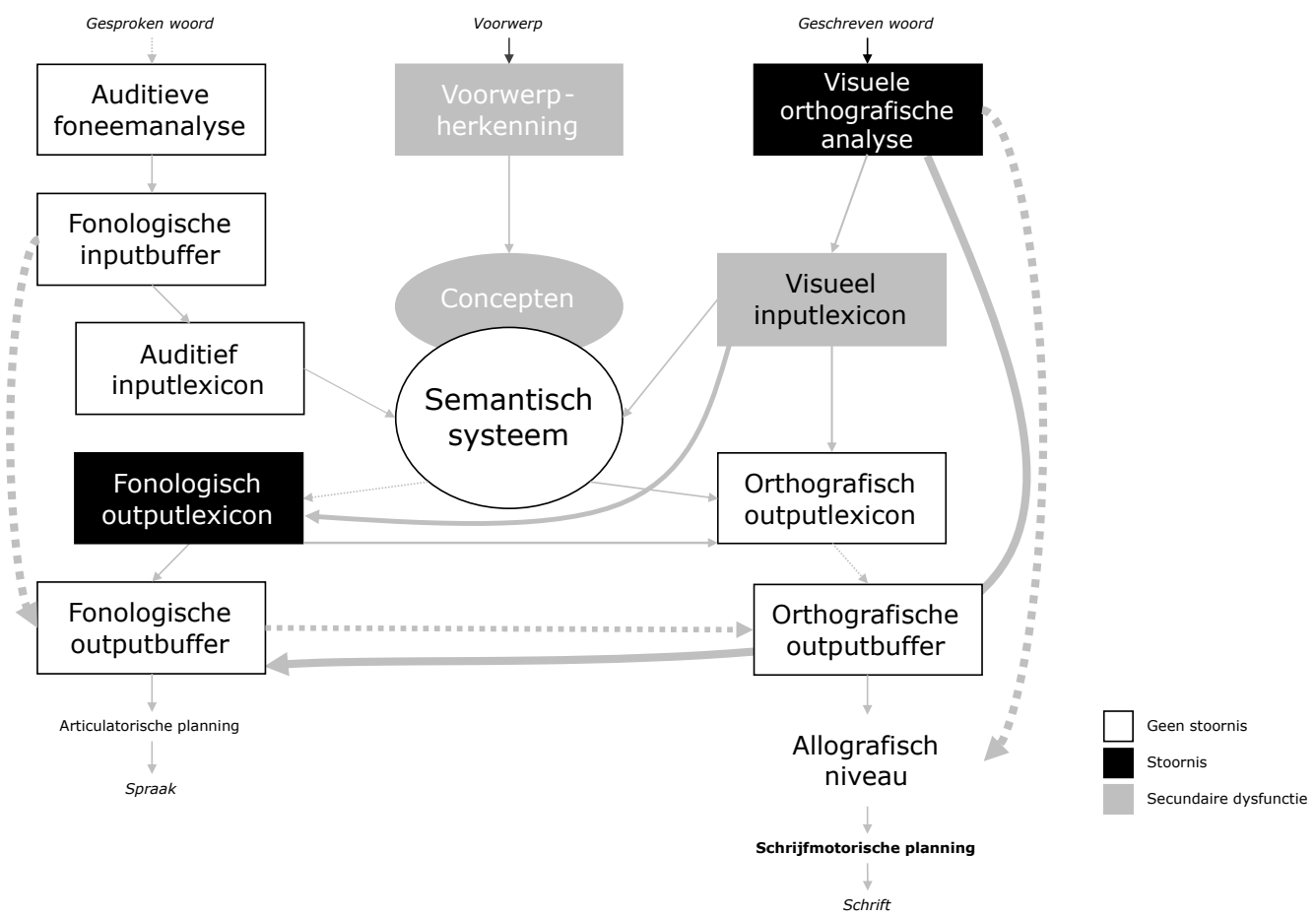

Figuur 3: De onderliggende taalstoornissen van E. in kaart gebracht naar het logogenmodel van Patterson \& Shewell (1987) en het taalverwerkingsmodel op woordniveau uit de Palpa (Bastiaanse, Bosje \& Visch-Brink, 1995).

\footnotetext{
${ }^{2}$ Voor een duidelijke en correcte weergave van het therapie-effect had direct na de intensieve oefenperiode een hertest afgenomen moeten worden. E. wilde op dat moment niet belast worden met tests. In het kader van dit artikel besloot E. om een jaar later alsnog aan een hertest mee te werken.
} 


\section{Situatie tot tien jaar post-onset}

E. is na haar revalidatie-behandeling gestart bij een activiteitencentrum, dat zij tot 2020 bezocht en waar zij deelnam aan neurogym, gespreksgroep en de afasiegroep. Thuis luisterde ze naar luisterboeken en kookt ze. Het alfabet werd nog vaak door E. gebruikt als ondersteuning bij het vinden van de juiste letter, of klank.

Zelf omschreef ze haar situatie zes jaar post-onset als volgt: "Het ergste van mijn ziekte is dat ik geen boek meer kan lezen. Ik doe verder alles weer. Ik schrijf mijn boodschappenlijstje wel, en eenmaal in de winkel kan ik uit de eerste letter afleiden welke boodschap ik bedoeld heb. Dat onthoud ik nu wel.

Mijn man leest me voor uit de krant, leuk als hij dat uit zichzelf doet. Soms lees ik een woord en weet ik waarover het gaat: dan ben ik trots. Het gaat goed, hoor."

Tien jaar post-onset meldde E. dat zij weer steeds vaker krantenkoppen las.

\section{Discussie}

Deze gevalsbeschrijving is een poging om elkaar beïnvloedende (talige, nonverbaal-semantische en visuele) stoornissen zorgvuldig te ontrafelen door middel van uitgebreide diagnostiek, met als doel de logopedische behandeling zo gericht mogelijk te kunnen geven. Moeilijkheid hierbij was dat de stoornissen in elkaar overliepen, waardoor de aard van de stoornissen niet duidelijk kon worden vastgesteld. Daarnaast was het diagnostisch bereik van linguïstiek en neuropsychologie te beperkt om het hele spectrum aan stoornissen in kaart te brengen. Daardoor was het moeilijk om een integrale, sluitende diagnose te stellen. Al met al bleef het hierdoor onduidelijk wat precies de grondslag was van de problemen met objectherkenning, herkennen van afbeeldingen, woordvinding en het lezen en schrijven. Op basis van de observaties en de verzamelde onderzoeksgegevens gingen we wel uit van een stoornis in de (semantische) conceptformatie en een ernstige alexie. Het klinische beeld (moeite met het activeren van concepten en semantische verwarringen) deed ons sterk denken aan een associatieve agnosie, maar het was geen zuiver beeld. Op basis van observaties en van de huidige theoretische kennis over deze stoornissen, zijn we de behandeling gestart. Behandelen op basis van werkhypothesen was in deze casus dus noodzakelijk. De werkhypothesen werden voor een belangrijk deel geformuleerd op basis van observaties tijdens de testafnames. Er is bij het testen dus bewust veelvuldig afgeweken van de standaardafnameprocedures, met als doel een zuiver beeld van de stoornissen te krijgen. Voorbeelden hiervan zijn in deze casusbeschrijving genoemd, zoals het semantisch doortesten bij het benoemen van kleuren (BE-2; AAT); zie 'Diagnostiek') en het verminderen van de visuele overprikkeling (crowding-effect) bij de SAT Visueel (zie 'Behandelperiode 2'). De aanpassing bij de SAT Visueel werd gedaan door middel van het afdekken van de responsmogelijkheden. Hierdoor kreeg E. de gelegenheid om enkel de doelafbeelding te bekijken, zonder afleidende stimuli, hetgeen E. in staat stelde om de test te maken. Door deze testaanpassing aan het crowdingeffect, werd de onderliggende stoornis duidelijker. Dit pleit bij meervoudige stoornissen voor aanpassing van de testcondities, wanneer stagnatie optreedt. Bij deze casus E. waren 
er omwille van het complete beeld van de stoornissen, duidelijke redenen voor het doelmatig manipuleren van de testconditie. In het besef dat afwijking van de afname-standaard de testafname minder betrouwbaar werd, kon alleen met deze alternatieve afname duidelijk worden dat de slechte score op de SAT Visueel bij E. niet volledig kon worden toegeschreven aan een stoornis in de (visuele) semantiek.

De SAT Visueel blijkt logischerwijs gevoelig voor meer visuele problemen dan uitsluitend de visueel-semantische problemen, maar toen gecorrigeerd werd voor het crowding effect en E. in staat was de test te maken, bleek de SAT Visueel in essentie nog steeds niet te voldoen aan onze behoefte om conceptactivatie volledig in kaart te brengen, omdat het enkel de visuele modaliteit van een concept onderzoekt. De SAT Visueel voldoet weliswaar aan de meetpretentie, namelijk het vaststellen van een visueel-semantische stoornis, maar het doel van de SAT Visueel is het vaststellen van visueel-semantische stoornissen, als mogelijke oorzaak van benoemstoornissen. Bij E. was de visueel-semantische stoornis echter niet de oorzaak van de benoemstoornis. De behandeling van E. vereiste een multi-modale benadering, waarvoor geen onderzoeksinstrument beschikbaar is. Voor zover bij ons bekend zijn er geen instrumenten die specifiek meerdere aspecten van conceptactivatie onderzoeken. Het UCO (Pijfers, De Vries, \& Messing-Peterson, 1985) of de Scenario Test (Van der Meulen, Gelder-Houthuizen, Wiegers, Wielaert, \& Van de Sandt-Koenderman, 2008) hadden waarschijnlijk kunnen bijdragen aan een completer beeld van de multi-modale conceptactivatie, maar werden vanwege de (visuele) overprikkeling niet afgenomen.

In dit artikel is beschreven dat middels diagnostiek, al dan niet aangepast, en observaties, duidelijk werd dat er een ernstig probleem was in de conceptactivatie, maar dit onvoldoende geobjectiveerd kon worden met de reguliere linguïstische en neuropsychologische tests. Daarnaast werd het stellen van een duidelijke conclusie met betrekking tot de conceptactivatie bemoeilijkt, omdat onvoldoende duidelijk bleef waar de stoornissen in elkaar overliepen en elkaar beïnvloedden.

In het revalidatieproces van E. moesten de werkhypothesen herhaaldelijk worden bijgesteld. Aanvankelijk leek de perifere alexie ('letteralexie') het meest belemmerende probleem. Uiteindelijk bleek echter een crowding-effect het grootste probleem, vooral de moeite met het bepalen van de letterpositie in een woord, en het lengte-effect. Zo werd in het onderzoek naar de woordvinding van E. een groot verschil gevonden tussen de 'reguliere' BBT en de VBBT: er leek sprake van optische afasie. Kenmerk van een optische afasie is echter dat een patiënt vanuit de tactiele modus de voorwerpen wél kan benoemen. Dit is in een behandeling getoetst en bleek niet het geval: ook vanuit de tactiele modus had E. problemen met het activeren van het concept van het voorwerp en daardoor met benoemen.

De schrijfproblemen van E. konden noch op basis van motorische noch op basis van visuele stoornissen worden verklaard. Omdat E. wel hardop kon spellen en CVC-woorden op dictaat kon leggen met letterblokjes, konden de schrijfproblemen evenmin verklaard worden vanuit een talig probleem: de grafemische outputbuffer was immers intact. De vraag rees of er sprake was van een schrijfapraxie, waarbij de ruimtelijke programmering van het schrijven is aangedaan. In het model van Ellis \& Young bevindt deze vaardigheid zich op het allografisch niveau van het model. Bij E. leek er juist op dit niveau een stoornis te zijn, omdat zij moeite had met het omzetten van de abstracte letterrepresentaties naar de concrete 
letters als zij ze zelf moest schrijven. Afasietherapeuten en klinisch linguïsten herkennen en onderkennen dit probleem wellicht niet voldoende, omdat er geen taak is voor het hardop spellen (in bijvoorbeeld de PALPA). Daardoor wordt een mogelijke onderliggende schrijfstoornis op allografisch niveau onvolledig in kaart gebracht. De gevolgen voor het schrijven zijn echter enorm en daarmee ook de invloed op het dagelijks leven. Dit was voldoende reden om in een latere fase van het herstel te kiezen voor behandeling op het allografisch niveau, in samenwerking met de ergotherapeut.

Ondanks de zeer belemmerende visuele problemen van E. was gerichte afasietherapie mogelijk en zinvol. Door haar over een langere periode gefaseerd te behandelen, het herstel te volgen en aan te sluiten bij de behoeften van E., kwamen we uiteindelijk in de chronische fase tot een specifieke linguïstische behandeling van de lees- en schrijfstoornis, die effect had op meerdere niveaus. Beperking van deze casus is dat we de vooral specifiek linguïstische effecten hebben gemeten, maar niet de mogelijke effecten op (de kwaliteit van) het dagelijks leven. Vooruitgang op de specifiek linguïstische maten en de door E. en haar man gerapporteerde vooruitgang in het dagelijks leven (hoe beperkt ook) en een toegenomen gevoel van welbevinden passen in de visie dat intensieve behandeling van complexe cognitieve stoornissen ook nog langere tijd post-onset effectief kan zijn. Zo bewezen Breitenstein et al. (2017) dat intensieve spraak-taaltherapie van 10 uur of meer per week gedurende drie weken als een evidence-based interventie kan worden beschouwd bij patiënten van 70 jaar of jonger met chronische afasie na een cva. Voor E. was drie uur per week gedurende vier weken intensief en voor haar het maximaal haalbare. Vanuit wetenschappelijke studies naar effectiviteit van therapie kan een 'kritisch omslagpunt', of een 'ondergrens' van effectiviteit niet voorspeld worden. Mogelijk dragen deze en vergelijkbare casusbeschrijvingen bij aan een verruiming van de definitie 'intensieve therapie'.

\section{Met dank aan:}

Mw. E., haar echtgenoot en hun zoon A.; Marieke Kool, Willemijn Doedens, Mirjam Kouwenhoven, Suzanne Roubroeks, Anky van Asselt, Nicole ter Wal, Erik Hille Ris Lambers, Irma Sprangers, Karin van Nispen, Anne Visser-Meilly, Tanja Nijboer, Peter van Vierzen en Jonne van Lunteren.

\section{Referenties}

Bastiaanse, Y.R.M. (2010a). Afasie. Houten: Bohn Stafleu van Loghum.

Bastiaanse, R. (2010b). ATP Auditief TaalbegripsProgramma. Houten: Bohn Stafleu Van Loghum.

Bastiaanse, R., Bosje, M. \& Visch-Brink, E.G. (1995). PALPA, vertaling in, aanpassing aan en normering voor het Nederlands van de PALPA, Psycholinguistic Assesments of Language Processing in Aphasia. Hove: Lawrence Erlbaum Associates. 
Boxum, E., van der Scheer, F., \& Zwaga, M. (2013). Analyse voor Spontane Taal bij Afasie (ASTA). Standaard in samenspraak met de VKL. Vereniging voor Klinische Linguïstiek. Breitenstein, C., Grewe, T., Flöel, A., Ziegler, W., Springer, L., Martus, P., Huber, W., Willmes, K., Ringelstein, E.B., Häusler, K.G., Abel, S., Glindemann, R., Domahs, F., Regenbregt, F., Schlenk, K-J., Thomas, M., Obrig, H., Langen, E. de, Rocker, R., Wigbers, F., Rühmkorf, C., Hempen, I., List, J. \& Baumgärtner, A. (2017). Intensive speech and language therapy in patients with chronic aphasia after stroke: a randomised, open-label, blindedendpoint, controlled trial in a health-care setting. Lancet, 389, 1528-38.

Carramaza, A., Hillis, A.E., Rapp, B.C. \& Romani, C. (1990). The multiple semantics hypothesis: Multiple confusions? Cognitive neuropsychology, 7, 161-189.

Corsi, P.M. (1972). Memory and the Medial Temporal Region of the Brain. Proefschrift. Montreal: Department of Psychology. http://digitool.library.mcgill.ca/R/?func=dbin-jumpfull\&object_id=93903\&local_base=GEN01-MCG02

Deelman, B.G., M. Koning-Haanstra, W.B.G. Liebrand \& W. van den Burg (1981). SAN Test, een afasie test voor auditief en mondeling taalgebruik. Lisse: Swets \& Zeitlinger.

Ellis, A.W. \& Young, A.W. (1993). Human Cognitive Neuropsychology. Hove: Lawrence Erlbaum Associates.

Graetz, P., De Bleser, R. \& Willmes, K. (1992). Akense Afasietest (AAT). Amsterdam: Hogrefe.

Heesbeen, I.M.E. \& Loon-Vervoorn, W.A. van (2001). Boston Benoemingstaak: uitbreiding van de Nederlandse normen, gecorrigeerd voor opleiding en leeftijd. In: I.M.E. Heesbeen. Diagnostiek en herstelmeting van taalproblemen na niet-aangeboren hersenletsel. Proefschrift Rijksuniversiteit Utrecht. Veenendaal: Universal Press.

Heesbeen, I. \& Sevat, R. (2001). BIPAC \& BEBA-handleiding. Amersfoort: Birkhoven.

Köbben-van Vessem, A. (1998). Kompro 2000. Westervoort: Stichting afasie Therapie/ Afasievereniging Nederland.

Martin A. (2007). The Representation of Object Concepts in the Brain. Annual Review of Psychology, 58(1), 25-45.

Martin, A. GRAPES (2015). Grounding representations in action, perception, and emotion systems: how object properties and categories are represented in the human brain. Psychonomic Bulletin \& Review, 23, 1-12.

Mcnorgan C, Reid J, Mcrae K. (2012). Integrating Conceptual Knowledge Within and Across Representational Modalities. Cognition, 118(2): 211-33.

Meulen, I. van der, Gelder-Houthuizen, J. van, Wiegers, J., Wielaert, S., \& Van de SandtKoenderman, M. (2008). Scenario Test. Houten: Bohn Stafleu van Loghum.

Nispen, K. van, van de Sandt-Koenderman, W.M.E, Mol, L. \& Krahmer, E.J. (2016). Pantomime Production by People with Aphasia: What are Influencing Factors? Journal of Speech, Language and Hearing Research, 59(4), 745-58.

Pijfers, L., De Vries, L.A., Messing-Peterson, H. (1985) Utrechts Communicatie Onderzoek (UCO), uitgever Pragma, 1985.

Ralph, M. A. L. (2013). Neurocognitive insights on conceptual knowledge and its breakdown. Philosophical Transactions of the Royal Society of London B: Biological Sciences, 369(1634), 20120392.

Ralph, M.A.L., Jefferies, E., Patterson, K. \& Rogers, T.T. (2017). The neural and computa- 
tional bases of semantic cognition. Nature Reviews Neuroscience, 18, 42-55.

Rey, A. (1941). Psychological examination of traumatic encephalopathy. Archives de Psychologie, 28, 286-340; secties vertaald door J. Corwin \& F.W. Bylsma, The Clinical Neurologist, 1993, 4-9.

Roomer E., Brok S., Hoogerwerf A., \& Linn, D. (2011). Handleiding Boston Benoemtaak 2011 - Een test voor woordvinding. Scriptie. Hogeschool Utrecht, Logopedie.

Shallice, T. (1993). Multiple semantics: Whose confusions? Cognitive neuropsychology, 10, 251-261.

Sprangers (2015). Wat vertelt de score op de SAT Visueel ons over het functioneren van het semantisch systeem? Scriptie. Utrecht: Universiteit Utrecht, Neuropsychologie.

Visch- Brink, E.G. \& Bajema, I.M. (2001). BOX, een lexicaal-semantisch therapieprogramma voor afatische patiënten. Lisse: Swets \& Zeitlinger.

Visch-Brink, E.G., Stronks, D.L. \& Denes, G. (2005). De Semantische Associatie Test. Amsterdam: Harcourt Test Publishers.

Vries, L.A. de. (1984). STAP: een computergestuurd oefenprogramma voor de behandeling van afasie. Tijdschrift voor Logopedie en Foniatrie, 56, 9-10.

Warrington, E.K. \& James, M. (1991). Visual Object and Space Perception Battery (VOSP). Oxford: Pearson.

Whitworth, A., Webster, J. \& Howard, D. (2006). A Cognitive Neuropsychological Approach to Assessment and Intervention in Aphasia. New York: Psychological Press. 